\title{
Effects of climate change and human activity on lake shrinkage in Gonghe Basin of northeastern Tibetan Plateau during the past 60 years
}

\author{
WU Duo*, CHEN Fahu, LI Kai, XIE Yaowen, ZHANG Jiawu, ZHOU Aifeng \\ College of Earth and Environmental Sciences, MOE Key Laboratory of Western China's Environmental Systems, Lanzhou \\ University, Lanzhou 73000, China
}

\begin{abstract}
Changes in the status of freshwater resources are a topic of major global, regional and local concern. This is especially so in the arid and semi-arid regions of China, where shortage of water resources plays a crucial role in limiting sustainable socioeconomic development, as well as in sustaining natural ecosystems. Recent climate change, as well as the effects of localized human activity, such as the use of water for irrigation agriculture, may have significant effects on the status of the water resources in the region. Here, we report the results of a study of changes in the areas of lakes in Gonghe Basin, northeastern Tibetan Plateau of China, over the last 60 years. The data were acquired from optical satellite images and demonstrate that the total water area of lakes in Gonghe Basin decreased significantly from the 1950 s to 1980 s. The cause is ascribed mainly to human activity including exploitation of farmland, against a background of increasing population; in addition, climatic data for the region demonstrate a minor drying trend during this period as the temperature increased slightly. After the construction of several reservoirs, significant amounts of water were redistributed to promote irrigation agriculture and we conclude that this caused a significant shrinkage of the natural lakes. However, both the area of farmland and the population size remained approximately constant after 1990. We conclude that the variation of the total area of lakes during the second period was mainly controlled by climatic factors (precipitation and temperature). As the regional temperature reached a new high, the area of some of the lakes decreased sharply before finally maintaining a relatively steady state. We emphasize that anthropogenic climate change and human activity have both significantly influenced the status of water resources in the arid and semi-arid regions of China.
\end{abstract}

Keywords: Gonghe Basin; lake shrinkage; climate change; human activity

Citation: WU Duo, CHEN Fahu, LI Kai, XIE Yaowen, ZHANG Jiawu, ZHOU Aifeng. 2016. Effects of climate change and human activity on lake shrinkage in Gonghe Basin of northeastern Tibetan Plateau during the past 60 years. Journal of Arid Land, 8(4): 479-491. doi: 10.1007/s40333-016-0125-5

Freshwater resources are fundamental for sustainable socioeconomic development. It is likely that ongoing and future climate change will have a significant impact on terrestrial water resources on a global scale (Oki and Kanae, 2006), especially since the reality of anthropogenic climate change can no longer be doubted (IPCC, 2013). In particular, the arid and semi-arid regions of China will almost certainly become progressively drier in the future (Sherwood and Fu, 2014), thus reducing the availability of water to sustain economic activity. In addition, changes in land use can also affect the distribution and status of water resources and several studies have demonstrated that

*Corresponding author: WU Duo (E-mail: wud_2008@lzu.edu.cn)

Received 2015-10-29; revised 2015-12-17; accepted 2016-01-08

(C) Xinjiang Institute of Ecology and Geography, Chinese Academy of Sciences, Science Press and Springer-Verlag Berlin Heidelberg 2016 
even the alpine hydrologic environment in the Tibetan Plateau has been disturbed by human activities, including agricultural irrigation and settlement (Song et al., 2014a). Therefore, assessing the impact of natural and anthropogenic changes in the status of water resources in the region is critical for their effective administration and usage in the future.

Lakes are the primary terrestrial water reservoirs and monitoring changes in their status is essential for managing water resources and related ecosystem services (Wang et al., 2013). There is a rapidly growing literature focusing on changes in alpine lake on the Tibetan Plateau and their response to climate change (Phan et al., 2012; Song et al., 2013, 2014a, b, c; Zhang et al., 2013a, 2014; Lei et al., 2014; Yang et al., 2014). The Tibetan Plateau is the major source of several large rivers in Asia (Ma et al., 2011) and changes in its water resources will have a potentially critical impact on the livelihood of a large population in Asia (Immerzeel et al., 2010). With the use of optical satellite images, Ice, Cloud, and Land Elevation Satellite (ICESat) data, changes in water resources on the Tibetan Plateau can be assessed accurately. Most studies have focused on changes in the status of typical lakes: for example, they have documented the fact that while the level of Lake Qinghai decreased from the 1970s to the early 2000s, it began to increase after 2005 (Shen and Kuang, 2003; Li et al., 2011; Zhang et al., 2011a; Liu et al., 2013). Lakes Nam Co and Siling Co have also been studied from the perspective of the possible relationship between lake expansion and glacier melting in central Tibet (Zhou et al., 2013; Song et al., 2014a, b). In addition, there are ongoing investigations of lake level variations at the regional or whole plateau scales and the results demonstrate that lakes in different geographical and climatic sub-regions exhibit contrasting patterns of spatial and temporal variability (Zhang et al., 2011b, 2013b, 2014; Phan et al., 2012; Lei et al., 2013, 2014; Wang et al., 2013; Song et al., 2014b).

Relatively less attention has been paid to changes in the status of water resources in Gonghe Basin, located in the northeastern Tibetan Plateau which is a potential source area for global dust (Qiu et al., 2001; Chen et al., 2007; Pullen et al., 2011) and is also sensitive to climate change since it is situated closed to the modern monsoon limits (Chen et al., 2008). In the present paper, we use optical satellite images to estimate the area of lakes in Gonghe Basin during different periods and compare the results with various socioeconomic and climate data. The main aim is to attempt to reveal the main causes of changes in lake area during the past 60 years and therefore to aid in the establishment of appropriate management strategies for water resources against the background and challenges of ongoing climate change.

\section{Study area}

Gonghe Basin, located in the northeastern Tibetan Plateau, is situated south of Lake Qinghai and is separated from it by Qinghai Nanshan Mountain (Figs. 1a and b). The mean altitude of the basin is about 3,000 m asl. The mean annual precipitation was $315 \mathrm{~mm}$ from 1953-2013, based on instrumental records from Gonghe meteorological station, Qinghai province. The annual mean temperature and mean annual potential evaporation during this interval were $4^{\circ} \mathrm{C}$ and $1,717 \mathrm{~mm}$, respectively. More than $80 \%$ of the rainfall occurs from May to September, consistent with the high temperature and evapotranspiration (Fig. 1c). Shazhuyu River is the major interior river in Gonghe Basin, with a catchment area of about $8,000 \mathrm{~km}^{2}$. The relatively flat piedmont areas are highly suitable for farming and the basin has experienced an intensive phase of agricultural exploitation during the last few decades. Thus, several reservoirs have been built along the Shazhuyu River and its tributaries and large quantities of water have been diverted shortly after flowing from the mountains and have been used to irrigate farmland.

Previously, there were a series of lakes situated along the Shazhuyu River valley, most of which are dry at present. Currently these lakes are mainly supplied by precipitation runoff, as well as ground water, and water is lost through evaporation and seepage. Lake Dalianhai ('two lakes connected together' in Chinese) is the terminal lake of the Shazhuyu drainage basin. It is now a dry lake with a flat lake bed and gently sloping margins. Much work has been done to reconstruct the late Quaternary paleoclimatic history of the area, based on analysis of the lacustrine sediment 
record (Cheng et al., 2013; Sun and Colin, 2014). In addition, the history of lake level changes during the late Quaternary has been reconstructed and this work indicates that the lowest lake shore terrace was formed 1,500-2,000 years ago during the process of lake regression (Chen et al., 2012). The basin of Lake Yingdehai contains numerous small lakes, and immediately adjacent to the lake is the largest area of farmland in Gonghe Basin (area D in Fig. 1a). Lake Xinhu is situated alongside the Shazhuyu River and is fed by water derived mainly from Qinghai Nanshan Mountain. Lake Genggahai, whose maximum water depth is $1.8 \mathrm{~m}$, is fed mainly by groundwater (Qiang et al., 2013). All of these lakes are small and shallow and their areas are potentially highly sensitive to changes in water volume.
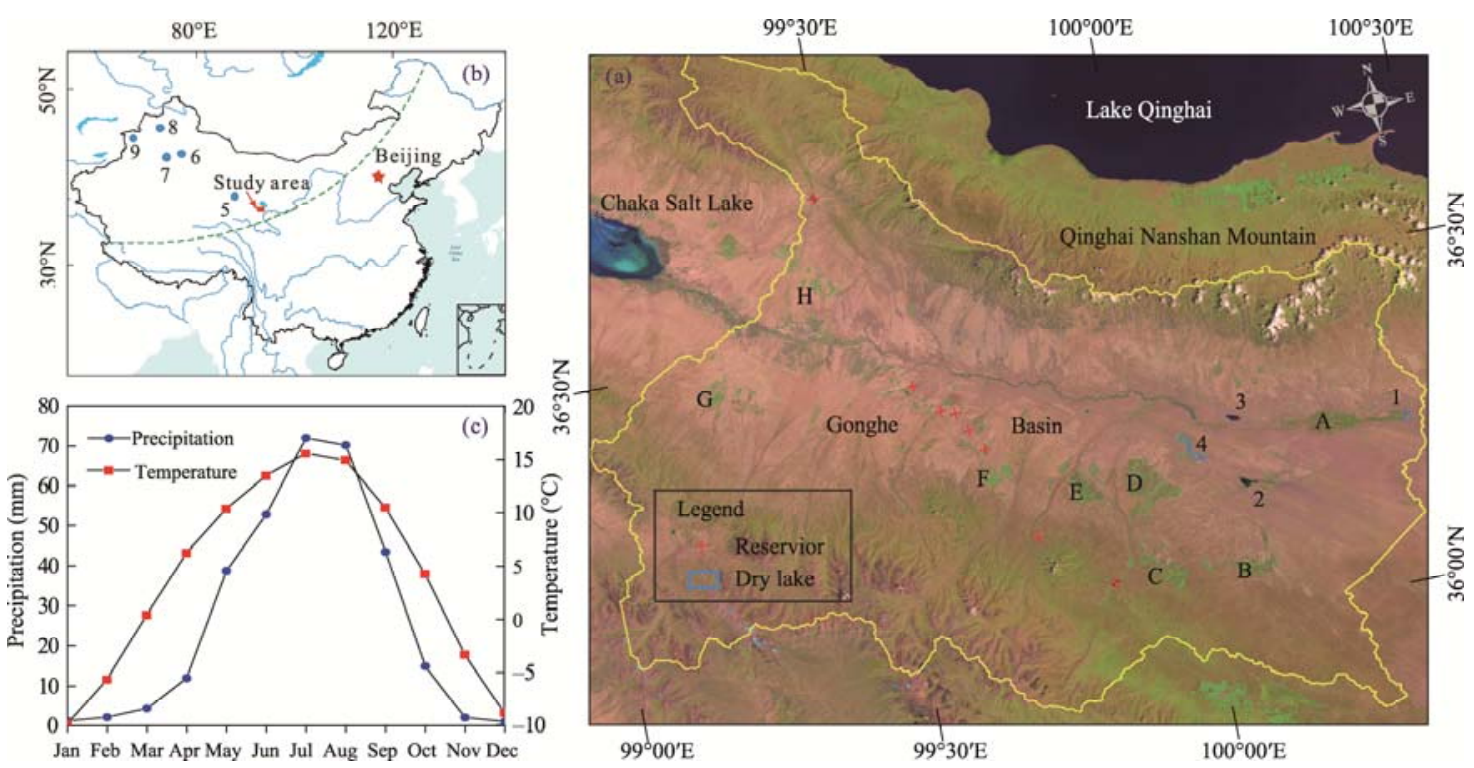

Fig. 1 (a) The catchment of the Shazhuyu River in Gonghe Basin and locations of reservoirs and farmland $(\mathrm{A}-\mathrm{H})$ and lakes (1-4); (b) Location of the study area (green dashed line indicates the modern monsoon limits (Chen et al., 2008) and blue dots (5-9) represent lakes mentioned in the text); (c) Instrumental climate data of monthly mean precipitation and temperature spanning 1953-2013 from Gonghe meteorological station, Qinghai province, China. 1, Lake Dalianhai; 2, Lake Genggahai; 3, Lake Xinhu; 4, Lake Yingdehai; 5, Lake Tuosu; 6, Lake Aydingkol; 7, Lake Bosten; 8, Lake Manas; 9, Lake Sayram.

\section{Materials and methods}

\subsection{Meteorological data}

Instrumental climatic data from Gonghe meteorological station were downloaded from the Climatic Data Center of the Chinese Meteorological Administration. The meteorological station provides high quality daily observations of air temperature and precipitation. Based on these daily data, we calculated monthly and annual precipitation and mean temperature spanning the interval 1953-2013.

\subsection{Optical satellite images}

We used one scene of the Landsat MSS/TM/ETM images covering the study area to retrieve data on lake surface extent at different dates from the late 1970s to 2014. Most of the data has a spatial resolution of $30 \mathrm{~m}$. Detailed information on the acquisition dates is provided in Table 1. For reducing the influence of seasonal variations when comparing inter-annual changes in lake surface extent, most of the images used in this research were limited to those acquired between August and October of each year. The lakes reach their highest level during this interval after receiving most of their precipitation during summer. All of the data were provided by the Geospatial Data Cloud, Computer Network Information Center, Chinese Academy of Sciences 
(http://www.gscloud.cn).

Lake boundaries were extracted in the single band image with manual delineation using ArcGIS 9.2 software. All map and image data were projected into the UTM coordinate system Zone 45 using the WGS-84 geodetic datum. The accuracy of manual digitization was controlled within one pixel. The lake areas in all of these images are cloud-free or only slightly cloud-covered (less than 10\%). The same method was also used to extract the area of farmland.

Table 1 Details of the satellite images used in this study

\begin{tabular}{|c|c|c|c|c|}
\hline Time series & Satellite/sensors & $\begin{array}{l}\text { Acquisition time } \\
\text { (dd/mm/yy) }\end{array}$ & Resolution (m) & Image scenes \\
\hline 1976 & Landsat 1-3 MSS & 22/04/1976 & 80 & 1 \\
\hline 1980s & Landsat 4-5 TM & 15/08/1987, 01/02/1989 & 30 & 2 \\
\hline $1990 \mathrm{~s}$ & Landsat 4-5 TM, Landsat 7 ETM SLC-on & $\begin{array}{l}\text { 28/08/1992, 27/05/1993, } \\
\text { 21/10/1994, 05/08/1995, } \\
\text { 24/09/1996, 27/10/1999 }\end{array}$ & 30 & 6 \\
\hline $2000 s$ & Landsat 4-5 TM, Landsat 7 ETM SLC-off & $\begin{array}{c}\text { 04/07/2001, 23/07/2002, } \\
31 / 01 / 2003,22 / 09 / 2004, \\
03 / 08 / 2006,22 / 08 / 2007, \\
16 / 08 / 2008,11 / 08 / 2009\end{array}$ & 30 & 8 \\
\hline $2010 s$ & $\begin{array}{l}\text { Landsat } 4-5 \text { TM, Landsat } 7 \text { ETM SLC-on, } \\
\text { Landsat } 8 \text { OLI_TIRS }\end{array}$ & $\begin{array}{l}\text { 14/08/2010, 16/07/2011, } \\
\text { 28/09/2012, 23/09/2013, } \\
06 / 06 / 2014\end{array}$ & 30 & 5 \\
\hline
\end{tabular}

\subsection{Historical documents}

Data on population and the area of farmland were obtained from historical documents (Zhang, 1991; Editorial Committee of Overview of Hainan Tibetan Autonomous Prefecture, 2009; Bureau of Statistics of Qinghai, 2014). The Bureau of Statistics of Qinghai maintains detailed records of the population and farmland area of Gonghe county, and the Annals of Gonghe county contain information about the date of construction and volume of reservoirs. Editorial Committee of Overview of Hainan Tibetan Autonomous Prefecture (2009) analyzed the factors responsible for influencing population variations in the region in the recent past and cited the importance of central government policies. In addition, lake area during the 1950s and the 1960s were cited from data acquired from air photographs (Shi et al., 1990; Zhao and Geng, 2004).

\section{Results and discussion}

\subsection{Changes in lake area}

The changes in the lake area are illustrated in Fig. 2 and listed in Table 2. Typical satellite images of different periods are also illustrated in Fig. 3. The total area of water in the Lake Dalianhai basin was around $3 \mathrm{~km}^{2}$ during the interval from the 1950s to the 1960s (Shi et al., 1990; Zhao and Geng, 2004), before beginning a decreasing trend until 1987. The rate of decrease of lake area was somewhat reduced from 1987 to 1993; however, an abrupt decrease occurred in 1994 and the lake had dried up completely by 1995.

It can be seen in Fig. 2b that the area of Lake Genggahai exhibited a decreasing trend from the 1950s until the late 1980s. The area of the lake was $7.6 \mathrm{~km}^{2}$ during the 1950s (Shi et al., 1990) and $4.8 \mathrm{~km}^{2}$ in 1987. The area increased from about $4.8 \mathrm{~km}^{2}$ in 1989 to almost $6 \mathrm{~km}^{2}$ in 1993, but after 1993 the area commenced a sharply decreasing trend with yearly fluctuations superimposed. From 2002 onwards, the area remained small, except for an increase in 2009-2011.

In the case of Lake Xinhu (Fig. 2c), it occurred around 1992 and it exhibited a fluctuating area during the last 20 years, with a mean of $1.24 \mathrm{~km}^{2}$.

Prior to the 1990s, the area of Lake Yingdehai (Fig. 2d) exhibited a similar trend to that of Lake Dalianhai and Lake Genggahai, a decrease from around $2.1 \mathrm{~km}^{2}$ during the 1950 s to $0.5 \mathrm{~km}^{2}$ in 1987 (Shi et al., 1990). After 1990, the lake area fluctuated with a similar pattern of annual variations as Lake Genggahai. 


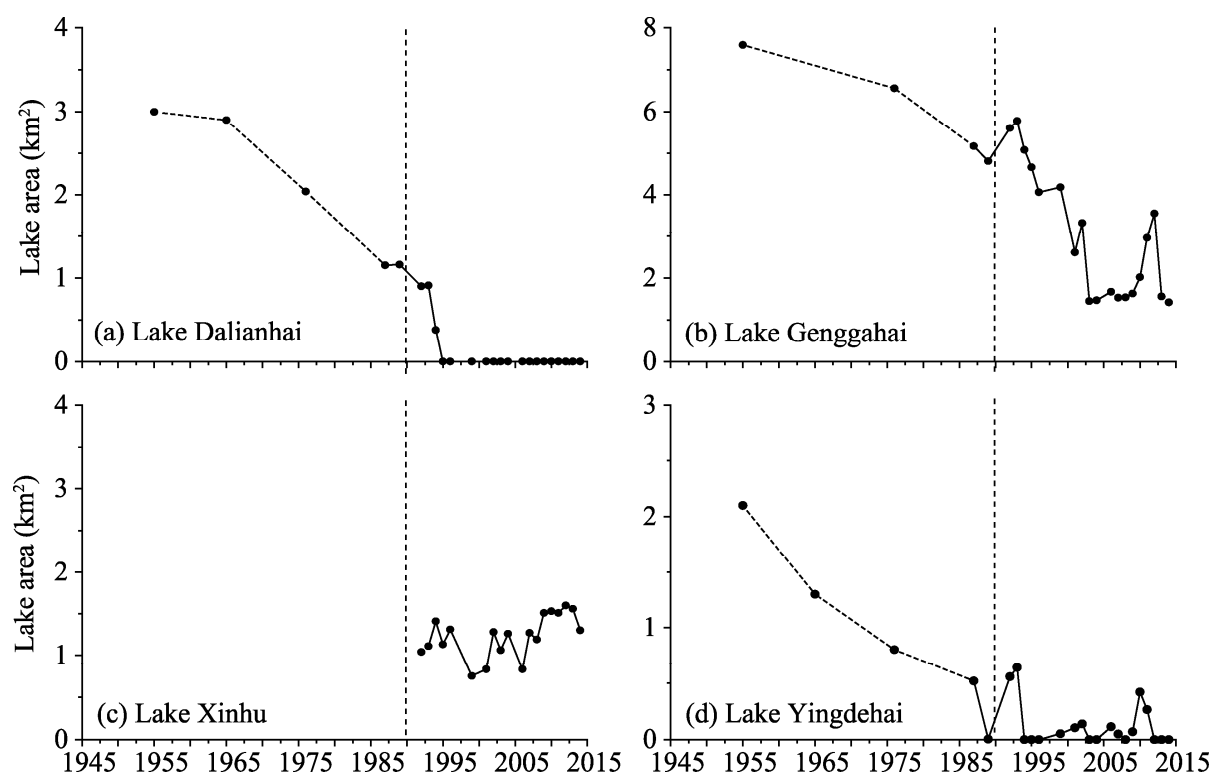

Fig. 2 Variation of the total area of lakes in Gonghe Basin during the past 60 years. Vertical dashed lines show boundaries between the main stages of lake evolution.

Table 2 Lake area data for four lakes from the 1950s to 2014

\begin{tabular}{|c|c|c|c|c|}
\hline \multirow{2}{*}{ Period } & Lake Dalianhai & Lake Genggahai & Lake Xinhu & Lake Yingdehai \\
\hline & \multicolumn{4}{|c|}{ Area $\left(\mathrm{km}^{2}\right)$} \\
\hline $1950 \mathrm{~s}$ & 3.00 & 7.59 & - & 2.10 \\
\hline $1960 s$ & 2.90 & - & - & 1.30 \\
\hline 1976 & 2.04 & 6.56 & 0.00 & 0.80 \\
\hline 1987 & 1.15 & 5.17 & 0.00 & 0.52 \\
\hline 1989 & 1.16 & 4.81 & 0.00 & 0.00 \\
\hline 1992 & 0.90 & 5.61 & 1.04 & 0.56 \\
\hline 1993 & 0.91 & 5.78 & 1.11 & 0.64 \\
\hline 1994 & 0.38 & 5.08 & 1.41 & 0.00 \\
\hline 1995 & 0.00 & 4.66 & 1.13 & 0.00 \\
\hline 1996 & 0.00 & 4.06 & 1.31 & 0.00 \\
\hline 1999 & 0.00 & 4.18 & 0.75 & 0.05 \\
\hline 2001 & 0.00 & 2.61 & 0.83 & 0.10 \\
\hline 2002 & 0.00 & 3.32 & 1.28 & 0.14 \\
\hline 2003 & 0.00 & 1.45 & 1.06 & 0.00 \\
\hline 2004 & 0.00 & 1.47 & 1.26 & 0.00 \\
\hline 2006 & 0.00 & 1.67 & 0.83 & 0.10 \\
\hline 2007 & 0.00 & 1.53 & 1.27 & 0.05 \\
\hline 2008 & 0.00 & 1.54 & 1.19 & 0.00 \\
\hline 2009 & 0.00 & 1.63 & 1.51 & 0.07 \\
\hline 2010 & 0.00 & 2.02 & 1.53 & 0.42 \\
\hline 2011 & 0.00 & 2.96 & 1.51 & 0.26 \\
\hline 2012 & 0.00 & 3.55 & 1.60 & 0.00 \\
\hline 2013 & 0.00 & 1.56 & 1.56 & 0.00 \\
\hline 2014 & 0.00 & 1.42 & 1.30 & 0.00 \\
\hline
\end{tabular}




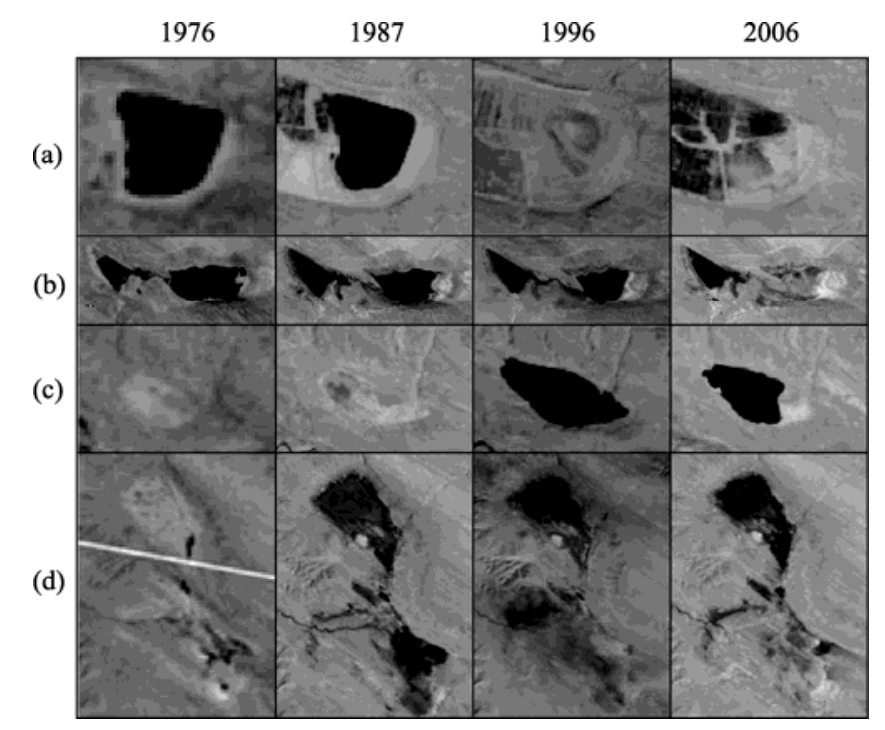

Fig. 3 Optical satellite images from different periods to illustrate variations in the water area of lakes in Gonghe Basin. (a), Lake Dalianhai; (b), Lake Genggahai; (c), Lake Xinhu; (d), Lake Yingdehai.

\subsection{Forcing mechanisms of lake area variation}

The volume of water in a lake varies according to changes in the hydrological budget. Lakes exhibit seasonal changes in surface area and level due to changes in precipitation and evaporation, and thus changes in lake water balance may be useful for providing improved information on regional and global climate changes and for the quantifying the human pressures on water resources (Cretaux et al., 2013). According to the variations of lake water area in Gonghe Basin and other climatic and economic data (Zhang, 1991; Bureau of Statistics of Qinghai, 2014), we divided the period 1950s-2014 into two intervals, as is shown in Fig. 4.

\subsubsection{0s-1980s: lake regression caused by human activity}

From the 1950s to the 1980s, the areas of three lakes exhibited an overall decreasing trend (Fig. 4f) which may have been the result of both climate change and human activity. Unfortunately, however, seasonal changes in lake area could not be captured because of the limited temporal resolution of the lake level data.

During this interval, the annual mean temperature varied from $2.5^{\circ} \mathrm{C}-4.5^{\circ} \mathrm{C}$ with a slightly increasing trend and with significant annual variations superimposed (Fig. 4d). The mean annual precipitation fluctuated on an annual basis between 150 and $550 \mathrm{~mm}$ with no clear long-term trend (Fig. 4e). Therefore, the trend of increasing temperature, rather than any change is precipitation, may have led to dry conditions in the basin and been partly responsible for the decreasing lake area. Lake Qinghai is located close to Gonghe Basin and its history of water level change could provide a valuable reference for understanding the variation of lake area in Gonghe Basin. As shown in Fig. 4g, the level of Lake Qinghai decreased during the period from the 1950s to the early 2000s, but it began to rise from 2004 onwards (Shen and Kuang, 2003; Li et al., 2011; Zhang et al., 2011a; Liu et al., 2013). This overall decreasing trend of lake level, at least until 2004, is accompanied by a trend of increasing temperature (Zhang et al., 2011a). Other studies also indicate that relatively warm and dry climatic conditions were responsible for the decline in the level of Lake Qinghai, and that the effect of human activity was limited (Qu et al., 1994; Li et al., 2011). In summary, the trend of increasing temperature from the 1950s onwards is clearly one of the main causes of the shrinkage of lakes in the northeastern Tibetan Plateau.

It is should be noted, however, that Gonghe Basin differs from the Lake Qinghai drainage basin in that it has experienced an intensive phase of human exploitation during the past few decades. Historical documentary data indicate that the population in Gonghe county increased almost on a yearly basis from the 1950s to 1980s. To meet the food requirements of the increasing population, 

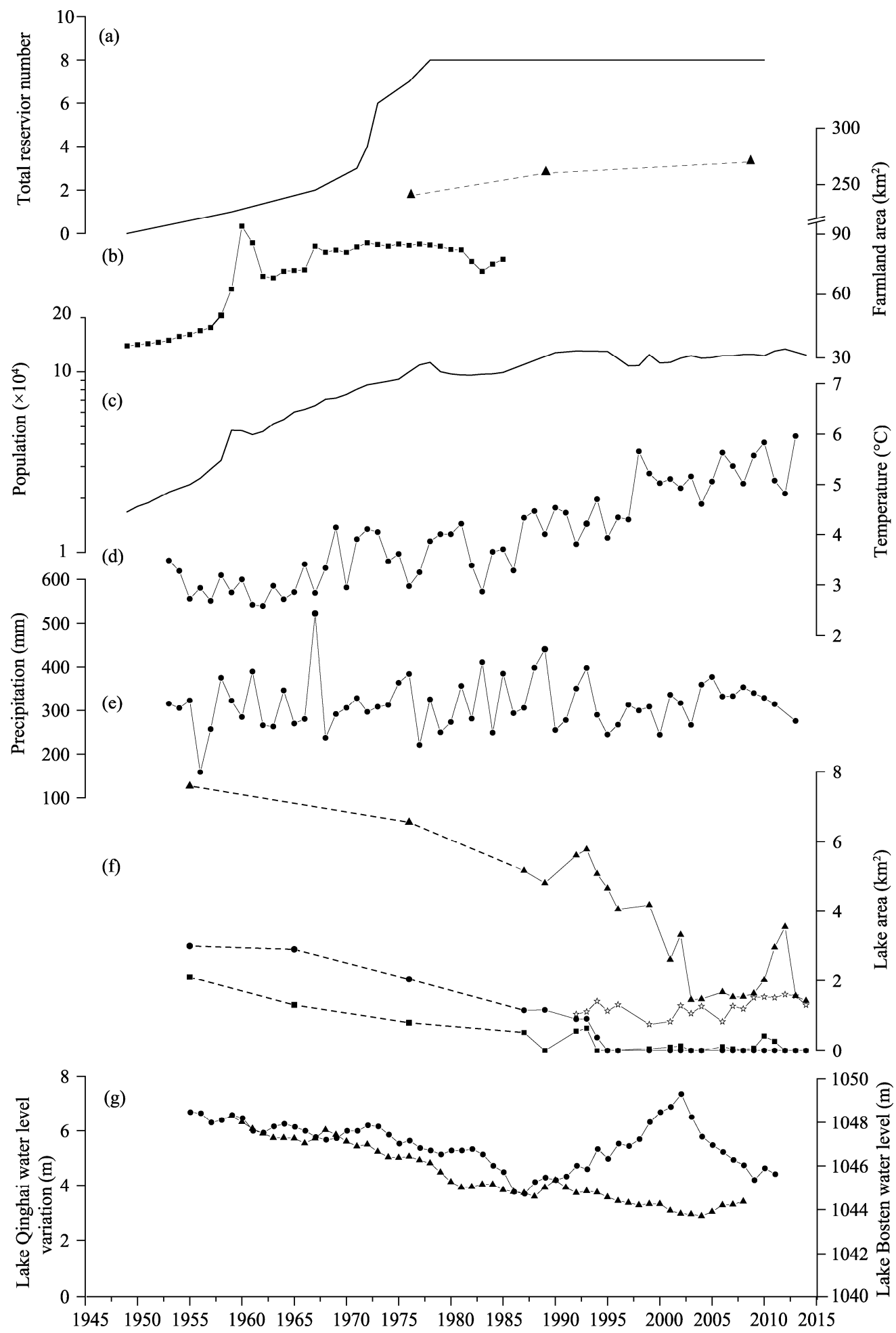

Fig. 4 Various parameters illustrating the relationship between the variation of lake area, climatic parameters and human activity during 1950-2013. (a) Number of reservoirs in Gonghe Basin at different intervals; (b) area of farmland in Gonghe Basin (squares represent data from historical documents and triangles represent data acquired from optical satellite images); (c) historical population of Gonghe county; (d) annual mean temperature; (e) mean annual precipitation; (f) change in lake area (triangles represent Lake Genggahai, dots represent Lake Dalianhai, squares represent Lake Yindehai and stars represent Lake Xinhu); (g) variation of the water level of Lake Qinghai and Lake Bosten water level (triangles represent Lake Qinghai and dots represent Lake Bosten). 
a large area of flat land was converted to arable land during this period (Zhang, 1991). Documentary data indicate that the area of farmland increased yearly, especially from around 1960 when the whole of China experienced the "great leap forward" (a political movement aiming at harnessing the natural environment) which formed rural people's communes. Gonghe county has belonged to the Hainan Tibetan autonomous prefecture since 1953. Soon after the establishment of the prefecture, thousands of immigrants, mainly from Gansu, Henan, Hebei, Tianjin and Shanghai arrived in the region. In particular, about twenty thousand people moved to occupy farmland in Gonghe county during the period from 1959 to 1960. Shortly afterwards, thousands of people emigrated from the region in order to escape the harsh living conditions and a significant amount of farmland was left unused from 1961 to 1962 (Editorial Committee of Overview of Hainan Tibetan Autonomous Prefecture, 2009), as shown in Fig. 4b.

In addition, several dams were constructed to irrigate farmland, since in arid and semi-arid regions of China the limited water resources are a major challenge for arable agriculture. Most of the dams were built during the 1960s and 1970s and this development of irrigation agriculture would inevitably have resulted in a reduction in the volume of stream flow and surface runoff to the lakes which would have had significant implications for lake levels. This situation is exemplified in the case of Lake Yingdehai. In the absence of human activity, surface runoff and stream flow would have been able to enter the lake through natural stream and river channels. Given the effects of human activities, it is highly probable that the development of arable agriculture, with the construction of a reservoir and associated irrigation channels, significantly affected the level of Lake Yingdehai which in fact dried up completely in the late 1980s.

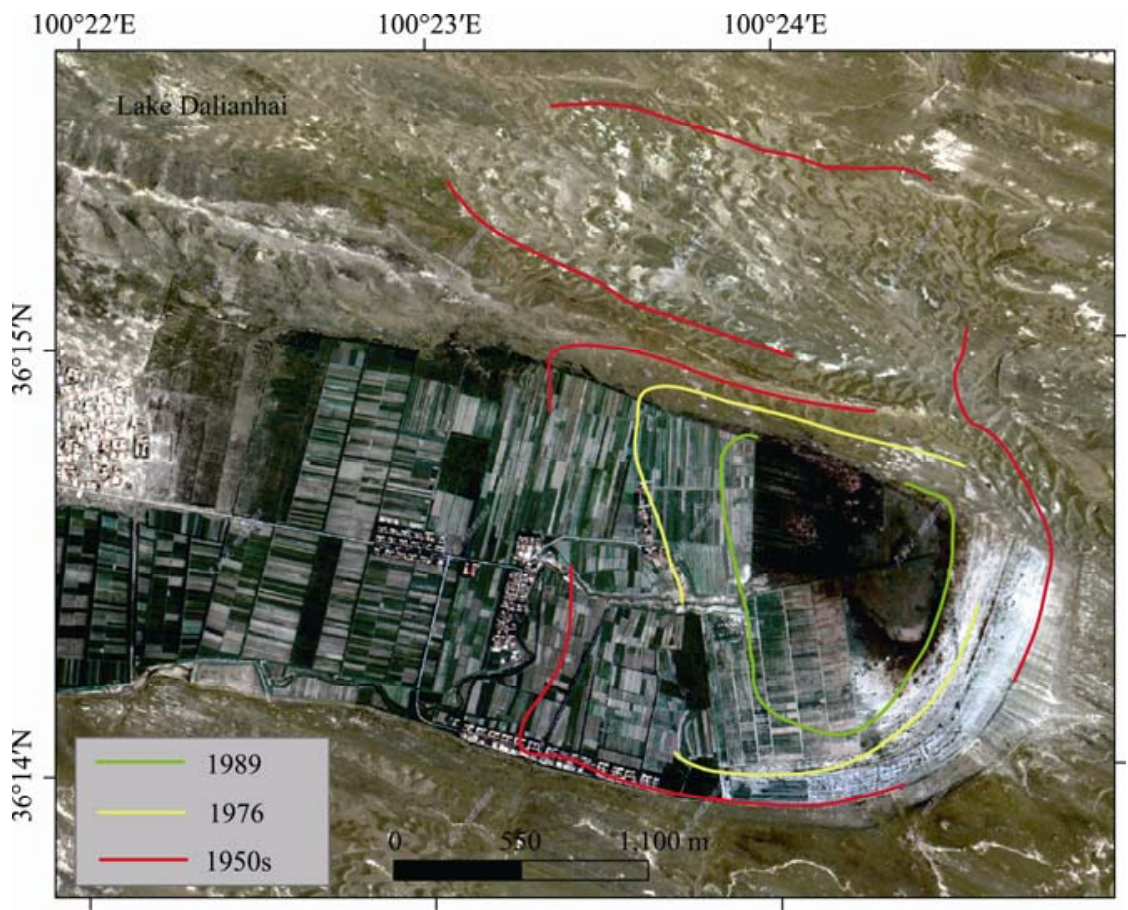

Fig. 5 Land use change resulting from the regression of Lake Dalianhai. The red line is an estimate of shoreline during the 1950s based on documentary evidence.

Thus it is clear that human activity can have a significant influence on the status of lakes, especially in semi-arid and arid regions. The level of Lake Bosten in Xinjiang exhibited a decreasing trend prior to 1987, and an increasing trend from 1987 to 2002 (Shi et al., 2007); however, the lake level decreased again after 2002 (Zhou et al., 2014). Zhou et al. (2014) analyzed lake level, temperature, precipitation and agricultural irrigation area data using the Mann-Kendall-Sneyers non-parametric statistical test and demonstrated that the water volume of Lake Bosten was mainly controlled by temperature and human activity before 1993 and by 
temperature afterwards. In addition, a study of Lake Tuosu in Qaidam Basin, west of Gonghe Basin, indicated that its water level variation was controlled by both evaporation and water usage for agricultural irrigation (Liu et al., 2014).

There is no doubt that in the recent past, human activity has played a more important role in controlling the variation of lake area in Gonghe Basin than climate change. Previous work has shown that against a background of a constant climate, lake catchments will eventually attain a balance between input and output of water and the lake areas will maintain a relatively steady state (Mason et al., 1994). Therefore, a relatively stable climate state cannot explain the decrease of lake area in Gonghe Basin during the study period and therefore human activity is likely to have been responsible for the observed changes.

As discussed above, human activity, including exploiting farmland and building dams, can significantly impact lake water resources and usually results in the decrease of lake levels. Clearly, a dry lake bed can also be exploited as new farmland. For example, the shoreline areas of Lake Dalianhai have been used as farmland since the area of the lake has decreased. It can be seen in Fig. 5 that most of the land in the Lake Dalianhai basin was under water during the 1950s, and even during the 1970s; however, the modern lake basin is now occupied by farmland and sand dunes.

\subsubsection{0s-2014: the role of anthropogenic climate change in reducing lake area}

The human population of Gonghe Basin was relatively stable during this period. Unfortunately, changes in the area of farmland were not well-documented from the mid-1980s to the early 2000s and therefore we calculated the area of farmland boundaries (Fig. 1(A-H)) from optical satellite images. The results indicate that the area of farmland remained relatively stable during this period. The number of reservoirs also remained constant. The most significant environmental factor to change during this period was the annual mean temperature, which varied from about $4^{\circ} \mathrm{C}-6^{\circ} \mathrm{C}$ with a mean of $5^{\circ} \mathrm{C}$. The mean annual precipitation also decreased slightly, with a pattern of annual fluctuations of lower amplitude than occurred previously. In terms of changes in lake area, Lake Dalianhai decreased sharply and it eventually dried up completely. The area of Lake Genggahai also decreased significantly, highlighting the drying process during this period. Lake Xinhu persisted, although its area fluctuated considerably. Lake Yingdehai fluctuated on a yearly basis, reappearing in years with higher precipitation.

Careful assessment of the annual variations in lake area and comparison with climatic records indicates that climate change was the dominant factor controlling the variation of lake area during this period. As shown in Fig. 6, when precipitation increases and temperature decreases respectively, lake area usually increases. Therefore lakes will expand over time with increased precipitation and decreased temperature. For example, the reappearance of Lake Xinhu and the transgression of Lake Genggahai and Lake Yingdehai, together with the reduction in the rate of decrease of Lake Dalianhai area in 1992, were mainly caused by increased precipitation and decreased temperature. The same conclusion can be drawn for the intervals 2001-2003, 2004, 2007 and 2009-2012.

The study of Shi et al. (2007) showed that in 1987 the climate changed from warm and dry to warm and wet in northwest China, most notably in the Xinjiang area. Therefore precipitation would have increased more than evaporation, and runoff would have increased and lake water levels risen. For example, as mentioned above, the level of Lake Bosten increased after the late 1980s. In addition, most of the lakes in Xinjiang, including Lake Aydingkol, Lake Sayram and Lake Manas, also expanded after the late 1980s (Ding et al., 2006). In addition, as suggested by Shi et al. (2007), the climate in regions such as the Tarim Basin, eastern Xinjiang and the northeastern edge of Qinghai province, including the catchments of Lake Qinghai and Gonghe Basin, changed slightly. However, the data presented here highlight the fact that the climate became warmer and dryer since the early 1990s in the northeastern Tibetan Plateau. In the case of Lake Qinghai, the longest interval of lake level increase since 2004 could be due to increasing precipitation and accelerated glacier/perennial snow cover melt in the region during recent decades (Li et al., 2011; Zhang et al., 2011a). 


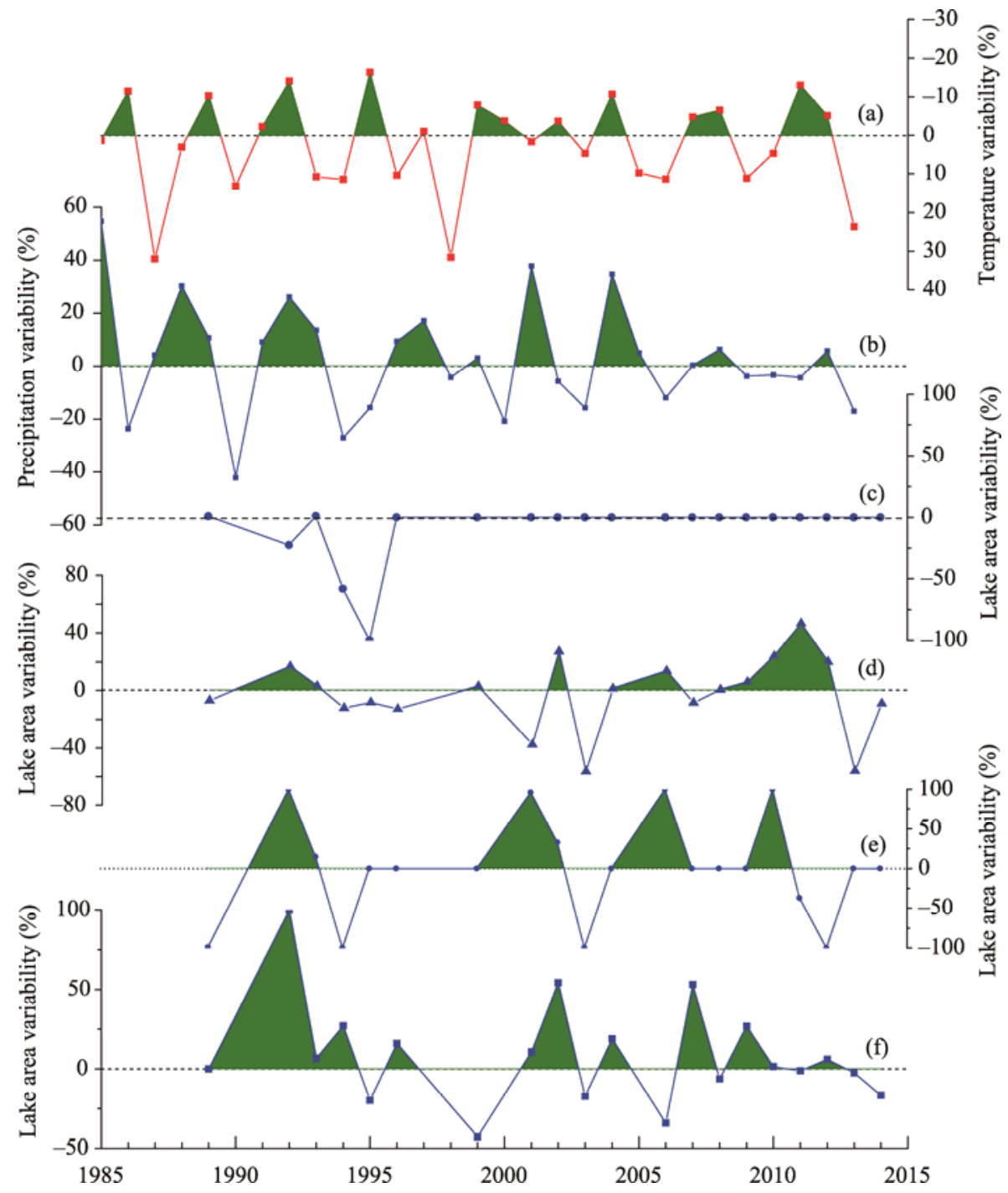

Fig. 6 Variation of climatic factors and the area of selected lakes in Gonghe Basin from 1989 to 2014. (a) Mean annual temperature; (b) mean annual precipitation; (c) area of Lake Dalianhai; (d) area of Lake Genggahai; (e) area of Lake Xinhu; (f) area of Lake Yingdehai.

\subsection{Comparison with other lakes on the Tibetan Plateau}

Remote sensing techniques have the advantages of relatively high spatio-temporal resolution, broad coverage and low cost, and they have already been used effectively to monitor changes in the area of lakes on the Tibetan Plateau and in the surrounding areas. A series of lake area data were derived from Landsat MSS/TM/ETM+ imagery and the ICESat/GLAS altimetry data for the past four decades (Phan et al., 2012; Song et al., 2013, 2014a, b; Zhang et al., 2013b, 2014; Lei et al., 2014).

Song et al. (2013) combined satellite altimetry data and optical remote sensing images to enable the comprehensive investigation of three-dimensional geometric changes in lake water storage using statistical models. The results show that the number and total area of lakes over 10 $\mathrm{km}^{2}$ in size in the Tibetan Plateau area increased gradually from the early 1970s to 2011; in addition the total lake area and total lake water storage also increased during this period. Lei et al. (2014) also showed that closed lakes on the Tibetan Plateau interior varied significantly during 1976-1999; however they expanded coherently and significantly in both area and water depth from 1999 to 2010. In addition, the results acquired from ICESat altimetry data indicate that over 
$70 \%$ of the lakes on the Tibetan Plateau showed an increase in water level between 2003 and 2009 (Zhang et al., 2011b, 2013a, Phan et al., 2012). Therefore, over the past forty years, the alpine lakes on the Tibetan Plateau have exhibited an overall expanding trend. However, the variations in individual lakes are dependent on the specific and potentially complex hydrological and climatic characteristics of their lake basins (Song et al., 2013).

Lu et al. (2005) compared three different groups of lakes: in the Nam Co basin, the Siling Co basin (both groups being supplied by both precipitation and glacial meltwater) and in the Yellow River source (supplied mainly by precipitation). They found that the first two groups expanded rapidly while the third group decreased by $3.77 \%$ between the late 1970 s and the early 2000s. Lei et al. (2013) showed that six closed lakes (Siling Co, Nam Co, Bam Co, Pung Co, Darab Co and Zigetang Co) expanded between 1976 and 2010, with a remarkable acceleration after 1999. Other lakes in the inner plateau, such as Zhari Nam Co, Tangra Yum Co, Lake UlanUla, Duoersuodong Co, decreased significantly in area from the early 1970s to the late 1990s, but expanded rapidly in the 2000s (Song et al., 2014b). However, lakes located on the southern fringe of the Tibetan Plateau, such as Peiku Co and Mapang Yum Co, exhibited a consistently decreasing lake level trend from 1972 to 2012 (Zhang et al., 2014).

In summary, the water level changes of different lakes over the plateau are spatially heterogeneous. In accordance with the results of the previous studies reviewed above, most of the lakes in the southern Tibetan plateau region and along the Himalayas, exhibit a trend of falling water level, while most of the lakes in the inner plateau exhibit a rising tendency (Song et al., 2014b).

The water balance of lakes in the region has undoubtedly been affected by climatic changes. Yang et al. (2014) showed that reductions in wind velocity on the Tibetan Plateau over the past 30 years may have weakened water vapor exchange between the Asian monsoon region and the plateau, leading to lower precipitation in the monsoon-impacted southern and eastern plateau. In contrast, they emphasized that increased convective precipitation over the central plateau was generated by the warmer and moister conditions, yielding more runoff; and at the same time, solar dimming reduced the rates of evaporation. These two factors, together with enhanced glacier melting, have contributed to the expansion of lakes in the central Tibetan Plateau. However, the contribution of glacial melt water to lake level change may be not obvious on a large spatial scale, since Phan et al. (2013) reported that more than half of the watersheds of Tibetan lakes are not linked to glaciers. In addition, Song et al. (2014d) also demonstrated that the expansion of lakes on the Tibetan Plateau in the 2000s was driven primarily by changes in precipitation and evapotranspiration and not solely by the effect of glacier melting. Therefore, the relationship between lake level variations and climatic forcing remains unclear (Song et al., 2014b).

\section{Conclusions}

Optical satellite images were used to estimate variation in the water areas of lakes in Gonghe Basin from the 1950s to 2013, and a comparison of the results with socio-economic and climatic data elucidates the main cause of the changes in lake area change during the study period. The changes in the status of lakes can be summarized as follows: (1) During the 1950s to the 1980s, the water area of Lake Dalianhai, Lake Genggahai and Lake Yindehai in Gonghe Basin decreased significantly. This was caused mainly by the exploitation of farmland against the background of an increasing population. Several reservoirs were constructed at the same time, and therefore a significant part of the runoff was redistributed to irrigate farmland, thus leading to lake shrinkage. (2) After 1990, the area of farmland and the population size remained roughly constant. The variation of lake area during this interval was controlled mainly by precipitation and temperature. Lake expansion occurred in years when precipitation was relatively high and temperature was relatively low. However, against the background of overall high temperatures during the study period, the water area of several lakes decreased sharply before reaching a relatively steady state thereafter. 


\section{Acknowledgements}

This research was supported by the National Natural Science Foundation of China (41372180), the Open Foundation of MOE Key Laboratory of Western China's Environmental System, Lanzhou University and the Fundamental Research Funds for the Central Universities (lzujbky-2015-bt01). We thank Bloemendal JAN for improving the English and LI Yuan from MOE Key Laboratory of Western China's Environmental Systems, Lanzhou University for constructive discussions.

\section{References}

Bureau of Statistics of Qinghai. 2014. Qinghai Statistical Yearbook 2014. Beijing: China Statistics Press. (in Chinese)

Chen F H, Yu Z C, Yang M L, et al. 2008. Holocene moisture evolution in arid central Asia and its out-of-phase relationship with Asian monsoon history. Quaternary Science Reviews, 27(3-4): 351-364.

Chen F H, Zhang J W, Cheng B, et al. 2012. Late Quaternary high lake levels and environmental changes since last deglacial in Dalianhai, Gonghe Basin in Qinghai province. Quaternary Sciences, 32(1): 122-131. (in Chinese)

Chen J, Li G J, Yang J D, et al. 2007. Nd and Sr isotopic characteristics of Chinese deserts: Implications for the provenances of Asian dust. Geochimica et Cosmochimica Acta, 71(15): 3904-3914.

Cheng B, Chen F H, Zhang J W. 2013. Palaeovegetational and palaeoenvironmental changes since the last deglacial in Gonghe Basin, northeast Tibetan Plateau. Journal of Geographical Sciences, 23(1): 136-146.

Cretaux J F, Letolle R, Bergé-Nguyen M. 2013. History of Aral Sea level variability and current scientific debates. Global and Planetary Change, 110(Part A): 99-113.

Editorial Committee of Overview of Hainan Tibetan Autonomous Prefecture. 2009. Overview of Hainan Tibetan Autonomous Prefecture. Beijing: The Ethnic Publishing House, 56. (in Chinese)

Ding Y J, Liu S Y, Ye B S, et al. 2006. Climatic implications on variations of lakes in the cold and arid regions of China during the recent 50 years. Journal of Glaciology and Geocryology, 28(5): 623-632. (in Chinese)

Immerzeel W, van Beek L P H, Bierkens M F P. 2010. Climate change will affect the Asian water towers. Science, 328(5984): $1382-1385$.

Intergovernmental Panel on Climate Change (IPCC). 2013. Climate change 2013: the physical science basis. In: Stocker T F, Qin D, Plattner G K, et al. Contribution of Working Group I to the Fifth Assessment Report of the Intergovernmental Panel on Climate Change. Cambridge, United Kingdom: Cambridge University Press.

Lei Y B, Yao T D, Bird B W, et al. 2013. Coherent lake growth on the central Tibetan Plateau since the 1970s: Characterization and attribution. Journal of Hydrology, 483: 61-67.

Lei Y B, Yang K, Wang B, et al. 2014. Response of inland lake dynamics over the Tibetan Plateau to climate change. Climatic Change, 125(2): 281-290.

Li L, Shi X H, Shen H Y, et al. 2011. Cause of water level fluctuation in Qinghai Lake from 1960 to 2009 and its future trend forecasting. Journal of Natural Resources, 26(9): 1566-1574. (in Chinese)

Liu B K, Wei X L, Du Y E, et al. 2013. Dynamics of Qinghai Lake area based on environmental mitigation satellite data. Pratacultural Science, 30(2): 178-184. (in Chinese)

Liu X X, Wen Z H, Shu L C, et al. 2014. Analysis of surface area changes of Keluke and Tuosu lakes over past 40 years and influencing factors. Water Resources Protection, 30(1): 28-33, 63. (in Chinese)

Lu A X, Yao T D, Wang L H, et al. 2005. Study on the fluctuations of typical glaciers and lakes in the Tibetan Plateau using remote sensing. Journal of Glaciology and Geocryology, 27(6): 783-792. (in Chinese)

Ma R H, Yang G S, Duan H T, et al. 2011. China’s lakes at present: Number, area and spatial distribution. Science China Earth Sciences, 54(2): 283-289.

Mason I M, Guzkowska M A J, Rapley C G, et al. 1994. The response of lake levels and areas to climatic change. Climate Change, 27(2): 161-197.

Oki T, Kanae S. 2006. Global hydrological cycles and world water resources. Science, 313(5790): 1068-1072.

Phan V H, Lindenbergh R, Menenti M. 2012. ICESat derived elevation changes of Tibetan lakes between 2003 and 2009. International Journal of Applied Earth Observation and Geoinformation, 17: 12-22.

Phan V H, Lindenbergh R C, Menenti M. 2013. Geometric dependency of Tibetan lakes on glacial runoff. Hydrology and Earth System Sciences, 17(10): 4061-4077.

Pullen A, Kapp P, McCallister A T, et al. 2011. Qaidam Basin and northern Tibetan Plateau as dust sources for the Chinese Loess Plateau and paleoclimatic implications. Geology, 39(11): 1031-1034.

Qiang M R, Song L, Chen F H, et al. 2013. A 16-ka lake-level record inferred from macrofossils in a sediment core from 
Genggahai Lake, northeastern Qinghai-Tibetan Plateau (China). Journal Paleolimnology, 49(4): 575-590.

Qiu X F, Zeng Y, Miao Q L. 2001. Sand-dust storms in China: temporal-spatial distribution and tracks of source lands. Journal of Geographical Sciences, 11(3): 253-260.

Qu Y G. 1994. Water balance and forecasting of water level change in Qinghai Lake. Journal of Lake Sciences, 6(4): $298-307$. (in Chinese)

Shen F, Kuang D B. 2003. Remote sensing investigation and survey of Qinghai Lake in the past 25 years. Journal of Lake Sciences, 15(4): 289-296. (in Chinese)

Sherwood S, Fu Q. 2014. A drier future? Science, 343(6172): 737-739.

Shi M Y, Guo L X, Yang H W, et al. 1990. The discussion about dry trend of lakes Yingdehai, Genggahai and Dalianhai in Gonghe Basin. Journal of Desert Research, 10(4): 51-55. (in Chinese)

Shi Y F, Shen Y P, Kang E S, et al. 2007. Recent and future climate change in northwest China. Climatic Change, 80(3-4): 379-393.

Song C Q, Huang B, Ke L H. 2013. Modeling and analysis of lake water storage changes on the Tibetan Plateau using multi-mission satellite data. Remote Sensing of Environment, 135: 25-35.

Song C Q, Huang B, Ke L H, et al. 2014a. Remote sensing of alpine lake water environment changes on the Tibetan Plateau and surroundings: A review. ISPRS Journal of Photogrammetry and Remote Sensing, 92: 26-37.

Song C Q, Huang B, Ke L H. 2014b. Inter-annual changes of alpine inland lake water storage on the Tibetan Plateau: Detection and analysis by integrating satellite altimetry and optical imagery. Hydrological Processes, 28(4): 2411-2418.

Song C Q, Huang B, Ke L H, et al. 2014c. Seasonal and abrupt changes in the water level of closed lakes on the Tibetan Plateau and implications for climate impacts. Journal of Hydrology, 514: 131-144.

Song C Q, Huang B, Richards K S, et al. 2014d. Accelerated lake expansion on the Tibetan Plateau in the 2000s: Induced by glacial melting or other processes? Water Resources Resesrch, 50(4): 3170-3186.

Sun Q F, Colin C. 2014. Paleoclimate and paleoenvironment of Gonghe Basin, Qinghai-Tibet Plateau, during the lastdeglacial: Weathering, erosion and vegetation cover affect clay mineral formation. Acta Geologica Sinica (English Edition), 88(2): $647-660$.

Wang X W, Gong P, Zhao Y Y, et al. 2013. Water-level changes in China's large lakes determined from ICESat/GLAS data. Remote Sensing of Environment, 132: 131-144.

Yang K, Wu H, Qin J, et al. 2014. Recent climate changes over the Tibetan Plateau and their impacts on energy and water cycle: A review. Global and Planetary Change, 112: 79-91.

Zhang G Q, Xie H J, Duan S Q, et al. 2011a. Water level variation of Lake Qinghai from satellite and in situ measurements under climate change. Journal of Applied Remote Sensing, 5(1): 053532, doi:10.1117/1.3601363.

Zhang G Q, Xie H J, Kang S C, et al. 2011b. Monitoring lake level changes on the Tibetan Plateau using ICESat altimetry data (2003-2009). Remote Sensing of Environment, 115(7): 1733-1742.

Zhang G Q, Yao T D, Xie H J, et al. 2013a. Increased mass over the Tibetan Plateau: From lakes or glaciers? Geophysical Research Letters, 40(10): 2125-2130.

Zhang G Q, Xie H J, Yao T D, et al. 2013b. Water balance estimates of ten greatest lakes in China using ICESat and Landsat data. Chinese Science Bulletin, 58(31): 3815-3829.

Zhang G Q, Xie H J, Yao T D, et al. 2014. Quantitative water resources assessment of Qinghai Lake basin using Snowmelt Runoff Model (SRM). Journal of Hydrology, 519(Part A): 976-987.

Zhang J. 1991. Annals of Gonghe County. Xining: Qinghai People’s Press. (in Chinese)

Zhao X B, Geng Z C. 2004. Reason of Dalian Lake dried up in Gonghe Basin. Science and Technology of Qinghai Agriculture and Forestry, (1): 19-20. (in Chinese)

Zhou H H, Li W H, Chen Y N, et al. 2014. Water-salt succession patterns (1951-2011) and its response to climate change in Lake Bosten. Journal of Lake Sciences, 26(1): 55-65. (in Chinese)

Zhou S Q, Kang S C, Chen F, et al. 2013. Water balance observations reveal significant subsurface water seepage from Lake Nam Co, south-central Tibetan Plateau. Journal of Hydrology, 491: 89-99. 